\title{
Mediating Knowledge Co-Production for Inclusive Governance and Delivery of Food, Water and Energy Services in African Cities
}

\author{
Temilade Sesan ${ }^{1}$ (D) . Safietou Sanfo ${ }^{2} \cdot$ Keneiloe Sikhwivhilu ${ }^{3} \cdot$ Francis Dakyaga $^{4}$. \\ Fati Aziz ${ }^{5}$. Dzidzo Yirenya-Tawiah ${ }^{6}$. Mercy Badu ${ }^{7}$ Emmanuel Derbile ${ }^{4}$. \\ Mercy Ojoyi ${ }^{8} \cdot$ Boubacar Ibrahim $^{9} \cdot$ Rabani Adamou ${ }^{9}$
}

Accepted: 19 August 2021 / Published online: 27 September 2021

(C) The Author(s) 2021

\begin{abstract}
Rising rates of urbanisation in Africa, without attendant improvements in critical infrastructure, have occasioned gaps in the provision of basic services in cities across the continent. Different systems and scales of service delivery - decentralised and centralised, public and private - coexist and often compete in urban spaces but rarely connect in ways that ensure the needs of the poorest are met. Our paper interrogates the value of transdisciplinary research for bringing actors in these systems together to co-produce knowledge for inclusive and sustainable outcomes. Drawing on empirical data from two complementary projects in four African cities, we demonstrate the possibilities for facilitating this kind of knowledge co-production among system actors in the food, water and energy domains. We show, through a comparative approach, elements of the co-production process that enable more responsive engagement by traditionally detached policy actors. From our findings, we generate a framework that local researchers serving as 'knowledge intermediaries' can use to stimulate research-policy-society interactions aimed at fostering sustainable and inclusive service delivery across Africa. By synthesising the findings from local case studies into a widely applicable framework, our analysis informs both the theory and practice of transdisciplinary sustainability research in the African context where the imperative to bridge gaps in methodological innovation and service delivery is high.
\end{abstract}

Keywords Food-water-energy systems $\cdot$ Inclusive governance $\cdot$ Knowledge co-production $\cdot$ Service delivery $\cdot$ Sustainable cities $\cdot$ Transdisciplinary research

Temilade Sesan

temi@gbengasesan.com

Extended author information available on the last page of the article 


\section{Introduction: Transdisciplinary Research and the Sustainability of Food, Water and Energy Systems in African Cities}

The world is experiencing rapid urbanisation. Approximately $60 \%$ of the global population will live in cities by the year 2030, with most of the growth occurring in Africa and Asia (Güneralp et al., 2017; UNDESA, undated). Although African cities are generally considered hubs of economic growth, contributing a high percentage of their countries' Gross Domestic Product (GDP), rapid urbanisation has resulted in the proliferation of informal settlements and pressure on available infrastructure for critical services (UN-Habitat, 2003). These pressures compromise the ability of African cities to meet the needs of current and future populations, making them important spaces to engage with in discourses and practices of sustainable development (Batinge et al., 2017; Kaviti Musango et al., 2020; Mguni et al., 2020). Compounding the problem, traditional policy responses to the infrastructure deficit in these cities have failed to address the specific vulnerabilities of the poor, who make up large swathes of the population within them (Nyiwul, 2021).

Of particular relevance for reducing vulnerability and increasing sustainability in the African context is mitigating perennial deficits in access to food, water and energy access among the urban poor (ibid.; Hottle \& Damassa, 2018). Dealing with these issues against the backdrop of SDG 11 - the sustainable development goal to make cities 'inclusive, safe, resilient and sustainable' — requires a move away from traditional siloed framings (WWAP, 2014; Schreiner \& Baleta, 2015) to more grounded approaches that recognise the naturally occurring interactions among the food, water and energy domains, as well as between them and other dimensions of the sustainable development agenda (Niessen et al., 2018; UNDESA, 2018). According to Lucas et al. (2019), for example, simultaneously improving access to food, water and energy among the poor in sub-Saharan Africa would yield over a quarter of the gains required to meet the SDG target on child mortality in the region by 2030 .

The case for linking up responses to deficits in food, water and energy infrastructure rests on the sustainability imperative of balancing material needs with ecological concerns (Kaviti Musango et al., 2020); however, doing so in a manner that is at once efficient and equitable - especially in African cities that have high baseline levels of poverty and 'social inequality' (Nyiwul, 2021; p.1) - presents a formidable challenge (Leck et al., 2018). While this kind of 'nexus' thinking has gained traction in recent years (see, for example, Sood et al., 2019; Adebiyi et al., 2021; Lefore et al., 2021), the debates have been largely framed in 'technomanagerial' terms (Mguni et al., 2020; p.1), focusing as they do on high-level exchanges between public and formal private-sector actors at the expense of the smaller-scale actors and interactions that make up life for the majority of the urban poor (Terrapon-Pfaff et al., 2018).

Conflicting perspectives by Robin et al. (2019) and Kaviti Musango et al. (2020) on the primacy that ought to be given to the framings of high-level actors (such as city authorities) versus those of lower-level stakeholders in sustainability 
debates indicate that there is a need to mediate conversations among stakeholders at these different levels. Our paper picks up on these strands in the literature, going beyond conventional technological framings of sustainability issues to analyse how actors at different scales (from the community level to the city level) deliver critical food, water and energy services in the African context. Importantly, we demonstrate the value of employing a transdisciplinary research approach (Schneider et al., 2019) for facilitating those interactions towards the goal of achieving more sustainable and inclusive outcomes.

The limitations of traditional research methods with regard to their ability to respond to 'real-world' situations have been widely acknowledged (Brister, 2016; Esler et al., 2016; Smith \& Jenkins, 2015). Linked to this is the difficulty of interpreting global and regional compacts such as the 2030 Agenda embodying the SDGs and the African Union's Agenda 2063 in ways that are relevant to actors and systems at the local level (Aguiar et al., 2020). From the point of view of proponents of 'post-normal' science, these shortcomings amount to a crisis, the resolution of which will require researchers to work in new, collaborative ways to restore the legitimacy of science in society (Saltelli \& Funtowicz, 2017; Sarewitz, 2016). Transdisciplinary (TD) research, which engages academic and non-academic actors - communities, public authorities and practitioners — in knowledge co-production processes, has emerged over the last six decades as a way to employ the scientific method in tackling real-world problems and consequently bridge the science-society divide (Fischer et al., 2015; Jahn et al., 2012; Lang et al., 2012; Pohl et al., 2017).

While there is no single accepted definition of transdisciplinarity, there are a number of key elements that are widely recognised as markers of good TD research: salience (relevance and responsiveness to issues that are important to everyday people in local contexts); non-linearity (application to complex, 'wicked' problems that defy simple solutions); collaboration (the involvement of researchers and practitioners in various fields within and outside academia); and co-production (the integration of disparate methods, values and perspectives to emerge with hybrid forms of knowledge) (Brennan \& Rondón-Sulbarán, 2019; Filho et al., 2018; Lang et al., 2012; Max-Neef, 2005; Pohl, 2011; Sakao \& Brambila-Macias, 2018; Wahl \& Baxter, 2008). TD research is particularly suited to the broad field of sustainable development, given the interconnected nature of social and environmental systems and the very real consequences of shifts in resource availability for people in local contexts (Hirsch Hadorn et al., 2006; Schafer et al., 2010; Fischer et al., 2015). Further, the alignment of TD research processes with contextual priorities, and their focus on generating actionable knowledge, offers pragmatic advantages over traditional research methods for resolving sustainability problems (Roux et al., 2010; Steynor et al., 2016).

Notwithstanding the radical promise of TD research, however, its implementation presents practical and epistemological challenges. While the focus on doing research at a granular level can promote a deeper understanding of contextual realities, several authors have acknowledged the practical difficulties involved in trying to get stakeholders with diverse perspectives and value systems to collaborate and agree on a shared vision of legitimate problems and solutions (see, for example, Steynor et al., 2016; Soma et al., 2018; Kirby, 2019). In other words, the premise of the 
validity of multiple knowledges that is so central to TD research also presents the challenge of knowledge integration, one that must be met with a great deal of 'methodological innovation' (Schafer et al., 2010, p.114) if it is to be fruitful. Further, proponents of disciplinary research argue that the problem-led approach of TD research limits its ability to contribute to broader scientific discourses around sustainability (Hirsch Hadorn et al., 2006; Kirby, 2019).

Nonetheless, Fischer et al. (2015) contend that there is as yet insufficient application of TD research to sustainability problems, relative to the body of theoretical knowledge that exists on the subject. The authors therefore advocate for more applied research that demonstrates the utility of employing a TD approach in the pursuit of societal and sustainability goals. This call is especially relevant for Africa, where engagement rarely occurs between city-level actors and other stakeholders and epistemological differences between policy makers and local communities can be very wide (Ambole et al., 2019; Rist et al., 2004). In this context, Ambole et al. (2019) call for local researchers to be 'knowledge intermediaries' who facilitate processes of co-production between policy and societal actors with the aim of making access to critical urban services more sustainable, equitable and inclusive. Some work has been done in this regard (see, for example, ISC, 2020; Sesan \& Siyanbola, 2021); however, much of it follows traditional siloed approaches to the analysis of food, water and energy systems and does not reflect the interconnected nature of these systems in African cities and elsewhere (Battersby, 2013; Frayne \& McCordic, 2015; Peyton et al., 2015).

Our paper advances the debate by analysing the implementation and outcomes of TD research led by local researchers working at the intersection of food, water and energy systems in the context of four African cities (Johannesburg, Kitwe, Ouagadougou and Tamale). In doing this, the paper makes three main contributions to the literature on TD research and sustainable development. First, our findings add to the growing body of work enabling the integration of policy responses to food, water and energy challenges in the global south, making local progress on multiple SDGs more attainable. Second, we go beyond technology-focused analyses that favour high-level engagement to address the dimensions of governance and service delivery that are essential to the realisation of equitable access. Third, by interrogating the implementation of TD research in multiple contexts and then synthesising the findings across those contexts, we demonstrate how otherwise narrow empirical insights can contribute to the development of broader theoretical frameworks in the field.

The paper begins with a conceptual categorisation of the actors and systems involved in the delivery of food, water and energy services in African cities. Next, we describe the research methods employed in our project cities, emphasising the elements of knowledge co-production that enabled fruitful interactions between system actors at multiple scales. We then discuss the outcomes of the research and reflect on their implications for the efficacy of transdisciplinary approaches intended to promote knowledge exchange and integration between societal and policy actors. The paper concludes by presenting an empirically derived framework aimed at advancing the theory and practice of transdisciplinary sustainability research in the African context. 
Public systems

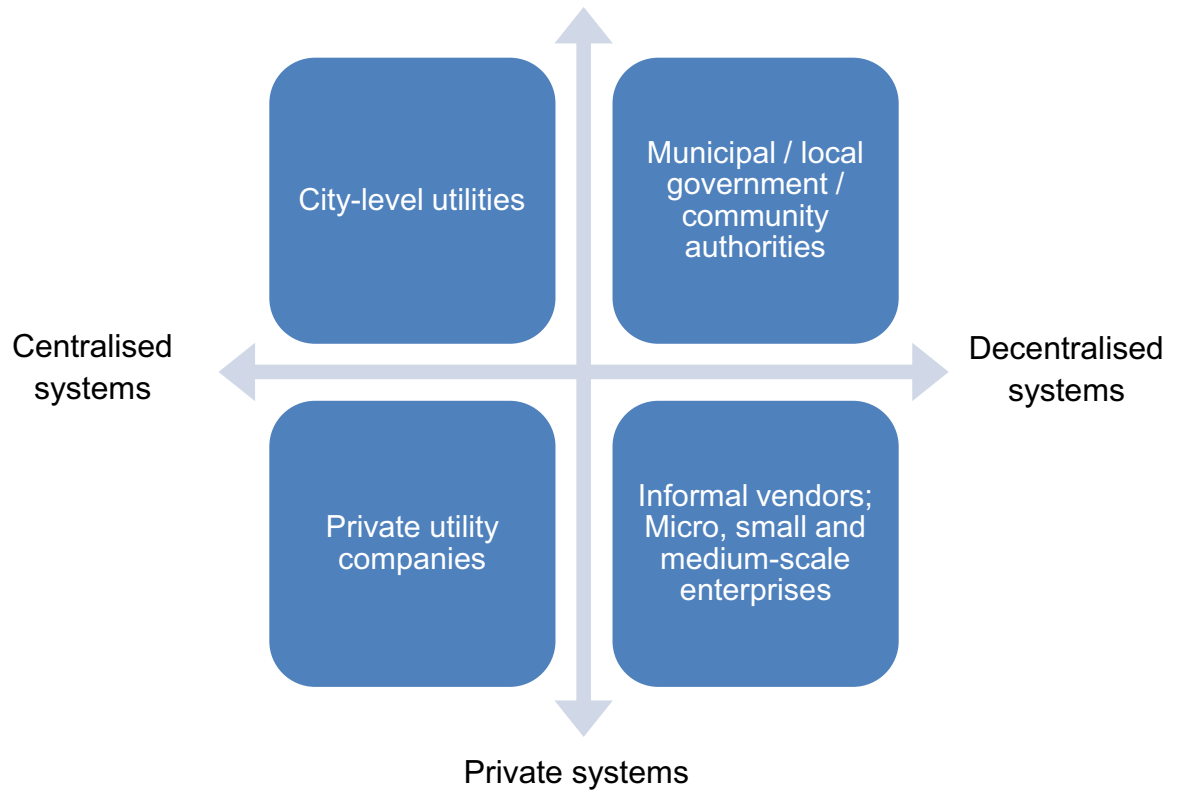

Fig. 1 The intersection of actors and systems for food, water and energy service delivery in African cities. Source: Authors' construct

\section{Systems of Governance and Service Delivery for Food, Water and Energy in African Cities}

There are various sets of actors involved in the provision of food, water and energy services in African cities, with varying characteristics. Our conceptual framework (see Fig. 1) locates these actors along two axes - public-private and centralised-decentralised - corresponding respectively to the modes of governance and service delivery associated with the systems within which they operate. The public-private axis of the framework denotes the functioning of stateowned utilities on the one hand and privately-owned systems on the other, while the centralised-decentralised axis makes a distinction between actors that operate networked, centralised systems and those that are more concentrated in specific localities.

Public utilities across Africa, especially those operating centralised systems, have long been associated with inefficiency (Herslund \& Mguni, 2019; Mbuvi et al., 2012; Sukholthaman et al., 2017). Other issues associated with public centralised systems have to do with the low quality, reliability and distribution of supply (Abubakar, 2016), as well as poor maintenance of delivery infrastructure such as water distribution pipes (Mugabi et al., 2007). Notwithstanding these shortcomings, demand still exists for public authorities to retain a role in governance and service delivery (Cheng \& Urpelainen, 2015; Cobbinah et al., 2017), even in areas such as 
urban food supply where state support has been historically weak or non-existent (Hubbard \& Onumah, 2001; Poulsen et al., 2015).

The case for state intervention has become even more urgent following the failure of much-lauded privatisation initiatives to significantly improve service delivery to the poor across the continent. Contrary to the early expectations of market enthusiasts, the takeover of water, energy and food governance by private actors in many African cities has neither improved the efficiency of centralised utilities nor increased the affordability and accessibility of their services for citizens (Araral, 2009; Bel \& Warner, 2008; Tan, 2012). Indeed, the notion of profit-making embedded in private enterprise would appear to preclude the pursuit of equitable access, with poor urban households being at a particular disadvantage under such systems (Schwartz et al., 2018; Visagie, 2008).

Moreover, privatisation has been shown to further weaken the legitimacy and capacity of public utilities to regulate the operations of private entities, with citizens often bearing the brunt of monopolistic practices and pricing (Castro, 2007). From both a governance and a service delivery perspective, it is becoming increasingly clear that centralised private systems are not a perfect substitute for public utilities in many African cities (Dakyaga et al., 2020). Even where private utility involvement has taken the form of public-private partnerships, the gains for public partners and citizens have been indeterminate, with success being more likely where profits to private partners are highest (Dellas, 2011; Devkar et al., 2013). Furthermore, experience has shown that merely applying the label of 'pro-poor' to such partnerships does not improve their ability to simultaneously meet the goals of equity and efficiency in governance and service delivery (Castro, 2007; Jones, 1995).

Decentralised models have been proposed in response to some of the challenges associated with centralised systems, whether public or private. Public decentralised systems, mostly governed by local government or community authorities, are built around the key principles of stakeholder engagement and local participation, even if the extent to which those principles are fulfilled in practice is limited (Dungumaro \& Madulu, 2003). The ideal of community participation has been shown to be especially problematic in low-income urban areas where expectations of equitable service delivery are often compromised by the disparate economic and political interests of the actors involved (Adams \& Zulu, 2015; Jimu, 2008).

Private decentralised systems, on the other hand, have been recognised as having the potential to drive the next wave of innovation in service delivery to poor urban households, on account of their flexibility and adaptability to the realities of African cities (Rabaey et al., 2020). In a challenge to the modernist aspirations of African city authorities, scholarly thinking has begun to coalesce around the utility of private decentralised systems and their compatibility with environmental sustainability goals (Herslund \& Mguni, 2019; Runsten et al., 2018). In particular, the role of informal service providers in bridging the gap left by public and private centralised utilities has been widely recognised in the literature, even though little policy attention has historically been paid to them (Dos Santos et al., 2017; Sima et al., 2013). The reality in many African cities is that these actors play a significant role in the delivery of affordable food, water and waste management services to poor urban households (Lourenco-Lindell, 1995; Matsinhe et al., 2008; Sima et al., 2013). 
Several authors (see, for example, Aparcana, 2017) have pointed out that the capacity of these actors to operate alongside formal providers needs to be strengthened, given that they will likely continue to be part of the service delivery landscape for some time to come.

Building on the foregoing analysis of the strengths and weaknesses of various actors and systems, we argue that responsive models of governance and service delivery that bring these systems together in action-oriented dialogue are required to realise more inclusive and sustainable outcomes, especially among the poor majority in African cities. This is the value that can be added by TD research, which facilitates the co-production of practical, evidence-informed solutions by stakeholders representing diverse systems. The paper goes on to describe how we used TD research as a methodology to facilitate system and stakeholder interactions in four project cities, the degree to which they enabled knowledge co-production for more inclusive governance of food, water and energy services in the project localities, and the implications of our findings for the applicability of TD research to similar sustainability issues in other African cities.

\section{Methodology}

\section{Research Approach}

The findings reported here are based on two distinct but complementary research projects. Both are part of a cohort of 28 projects across Africa that used TD research methods to address a range of SDG-related challenges in some of the continent's major cities from 2016 to $2021 .^{1}$

The first of our two projects explored actor/system interactions at the interface of water and energy provision in Johannesburg and Kitwe ('Project 1'), while the other facilitated those interactions at the interface of food, water and energy provision in Ouagadougou and Tamale ('Project 2'). The two projects were selected following a series of peer exchanges between the project leads and other researchers from the larger cohort described above. The main selection criteria were the chance that both projects offered to study the rich interconnections between food, water and energy and the wide geographical variation between them. The high degree of similarity between the focus of both projects, despite their situation in regions with different economic profiles (i.e. West and southern Africa), suggests that the findings from this synthesis will be broadly applicable to many African contexts even if they cannot be deemed generalisable. Further, and importantly, Project 2 seems to have fostered a greater degree of knowledge integration and consensus among

\footnotetext{
1 The projects, spread over three waves, were conducted under the auspices of the Leading Integrated Research for Agenda 2030 (LIRA 2030) in Africa programme administered by the International Science Council. A key aim of the programme is to support researchers based in African institutions in developing TD research capabilities for addressing a range of sustainability issues. The projects involved in this study ran from 2017 to 2020 .
} 
stakeholders than Project 1, presenting an opportunity to analyse elements of the research approach that contributed to more robust engagement in the former.

The two projects involved multidisciplinary research teams (i.e. from the natural and social sciences) working in collaboration with community, private-sector and policy actors in different configurations of public/private and centralised/decentralised systems within the project cities. On both projects, scientific research methods - in particular, spatial mapping, water quality and energy resource assessments, household surveys, transect walks, in-depth interviews, focus group discussions and participatory mapping — were employed in tandem with stakeholder engagement processes (see Table 1 for a breakdown of research methods used on each project). ${ }^{2}$ The aim of this transdisciplinary approach was to facilitate knowledge exchange between research and non-research actors in the study sites, with a view to identifying sustainable and inclusive solutions to the food, water and energy crises faced by residents. This resulted in an iterative process in which the design and direction of the research were informed by inputs from publics, policy makers and practitioners with hands-on experience of the issues involved; and the data gathered by the researchers, in turn, informed the content of successive engagements with the stakeholders.

\section{Study Areas}

The study sites for Project 1 were Diepsloot and Chambishi in the cities of Johannesburg and Kitwe respectively (see Figs. 2 and 3). Diepsloot was established in 1995 as a temporary shelter for people who had been evicted from informal settlements elsewhere in Johannesburg (Sichilima et al., 2017), and it is now home to about 350,000 residents (www.diepsloot.com). Twaiteka ward in Chambishi is a much smaller settlement - population: 24,152 (www.citypopulation.de) - located in the Copperbelt province of Zambia. Notwithstanding the difference in size between the study sites, they share important features: both sites are rapidly growing townships located at the fringes, and they are populated by low-income residents who are disadvantaged in the distribution of the centralised water and energy services provided by the respective city authorities.

Project 2 was conducted in Ouagadougou (Burkina Faso) and Tamale (Ghana). Ouagadougou is a relatively large, sprawling city, with a population of about 2.5 million people (INSD, 2017), while Tamale is a more condensed city with about 427,054 residents (GSS \& MoH, 2008) (Fig. 4). Here again, similarities between the study sites make for interesting comparison: in the face of inadequate municipal arrangements for waste collection and disposal in both cities, there is significant yet underexplored potential for linking up food, water and energy systems with the common objective of repurposing the waste generated by these systems.

\footnotetext{
${ }^{2}$ The results of the empirical research conducted on these projects are reported elsewhere.
} 


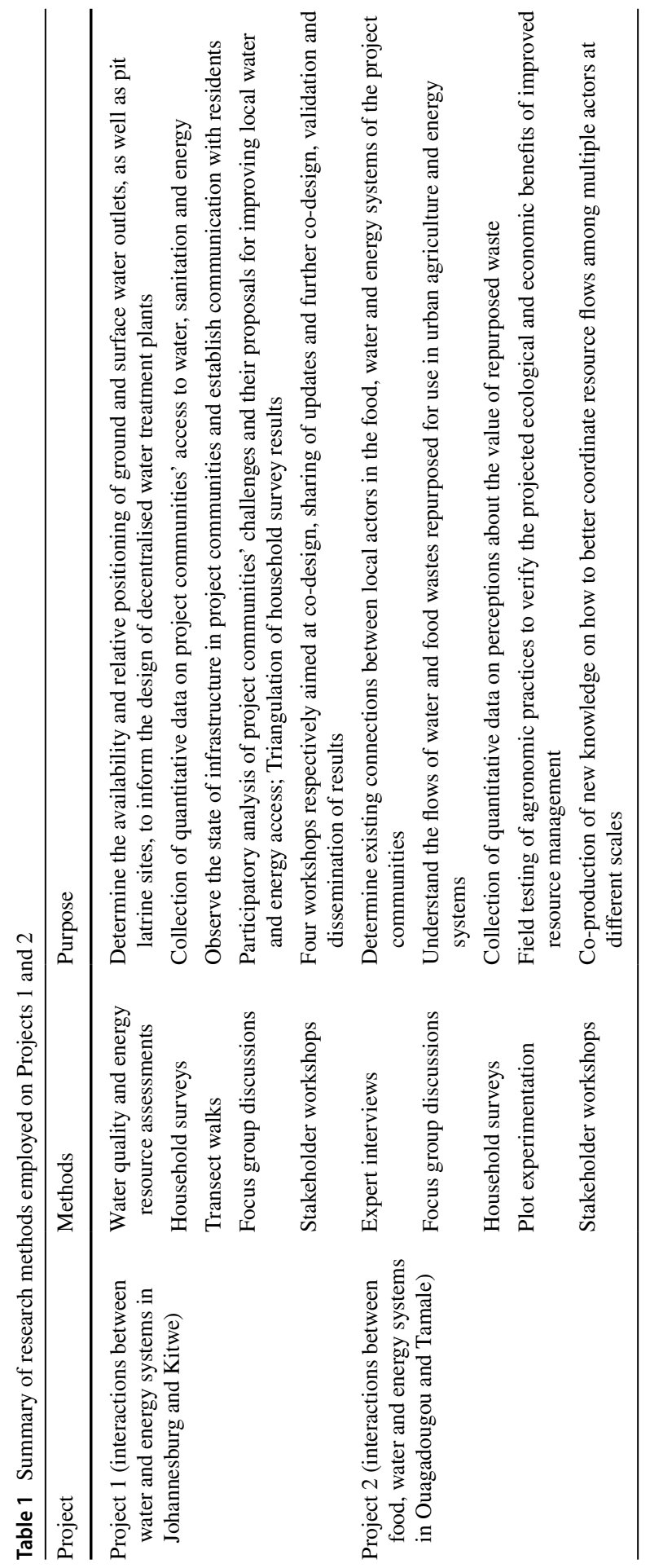




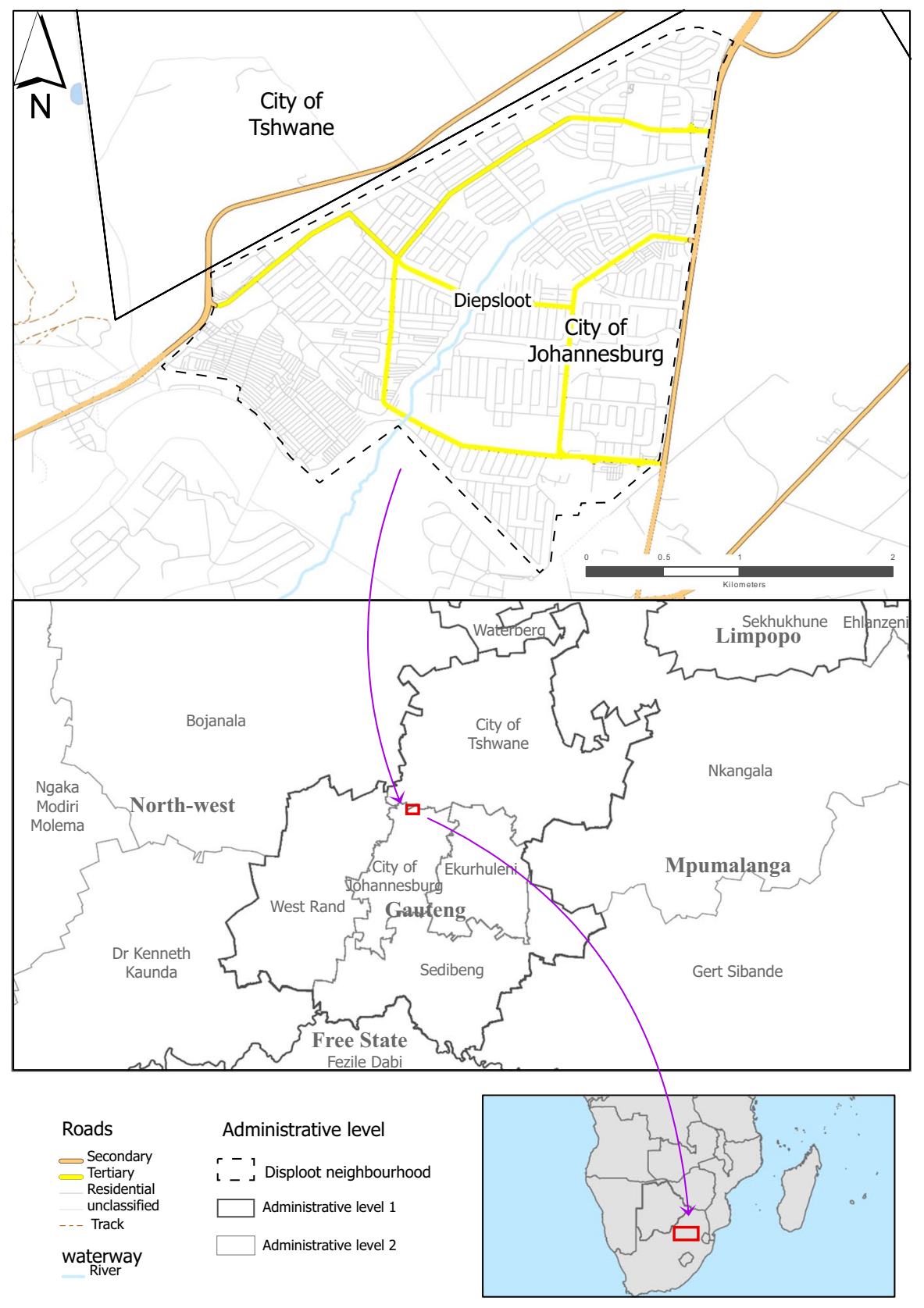

Fig. 2 Map of Diepsloot. Source: Authors' construct

\section{Knowledge Co-Production Processes}

As indicated in Table 1, dedicated stakeholder engagement events, a common denominator on Projects 1 and 2, were key platforms for the co-production of 


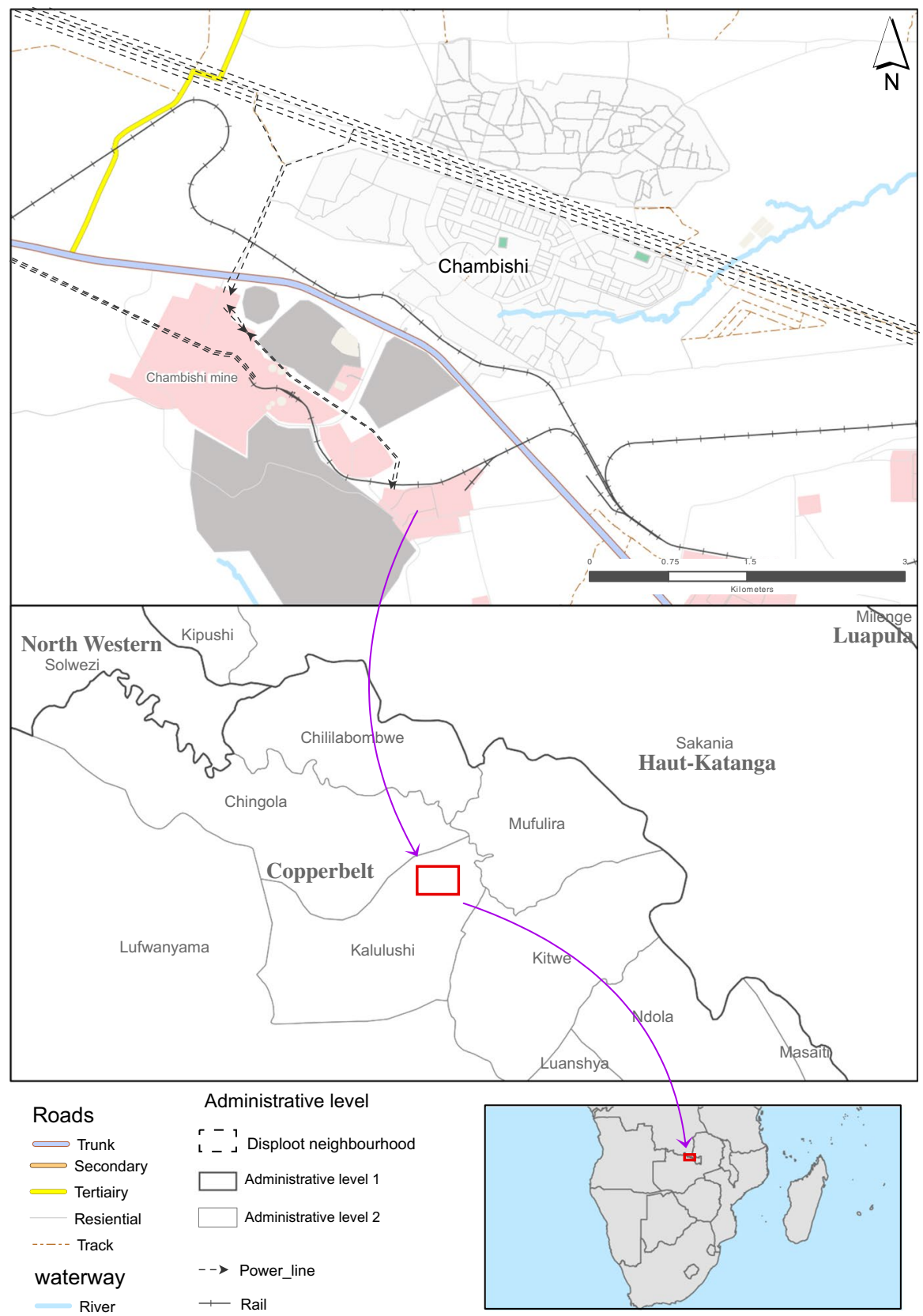

Fig. 3 Map of Chambishi. Source: Authors' construct

knowledge by the various actors involved. Four stakeholder engagement workshops were conducted on each project. On Project 1, the workshops - corresponding to co-design, sharing of updates and further co-design, validation and dissemination 


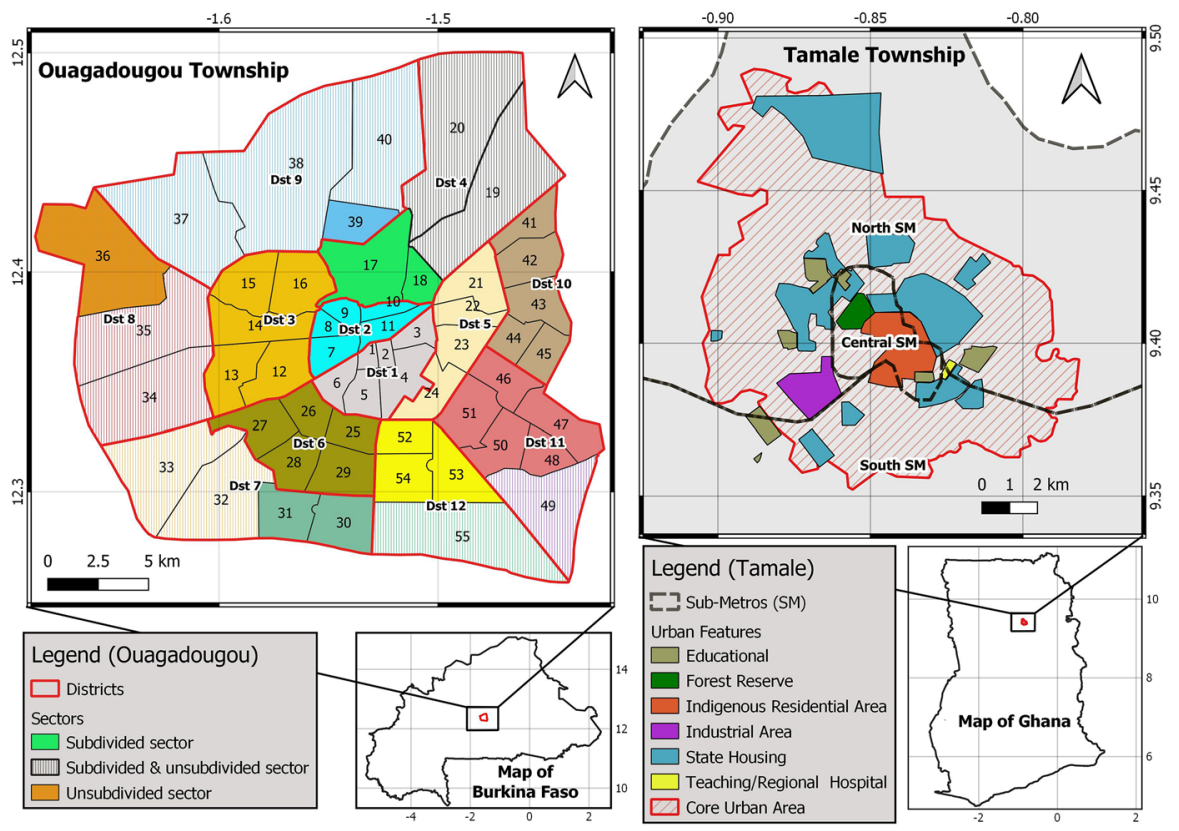

Fig. 4 Maps of Ouagadougou and Tamale. Source: Authors' construct

activities - involved officials from water and electricity utilities; regulatory agencies; civil society organisations working in the areas of water, sanitation and energy; and representatives of government departments at the city and municipal levels. The workshops on Project 2 focused on getting stakeholders on each site to engage reflexively with the realities of their respective food, water and energy systems, and to envision ways of channelling the waste from these systems more effectively. Workshop participants included: city and municipality officials in charge of health, sanitation, energy and agriculture; formal and informal waste collectors, sorters, transporters and processors; and small- and medium-scale actors in urban and periurban agriculture.

In line with the goal of our study to help develop the capacity of local researchers to serve as intermediaries at the interface of science and society in Africa, all the workshops were facilitated by academics based in the respective project cities. Nonacademic actors were invited to participate on the basis of their involvement in food, water and energy system management, both as practitioners and policy makers. The identification of relevant actors was not a one-time event; rather, it was a process that stretched from the proposal writing stage through to the project implementation phase, when in-depth interactions with various actor groups helped to refine the researchers' understanding of the configuration of local systems. The relative positioning of the researchers as outsiders to city, municipal and community structures presented access and communication challenges in the beginning. However, these difficulties eased as trust was gradually established with key system actors over the two-year project period. For these actors, the interactions enabled by the stakeholder 
workshops constituted an end in themselves; they did not share the interest of the academic facilitators in pursuing the analytical dimensions explored in this paper.

The next section begins by describing our findings on the state of food, water and energy systems in the project sites. Then, using the governance and service delivery framework presented above, we interrogate the degree to which the mediation done by the local research teams facilitated knowledge exchange and co-production among system actors in the project contexts. Of particular relevance is the degree to which the inclusion of private decentralised systems was enabled on each project, given that these are the systems that are most accessible by the urban poor. Finally, we condense the insights from this comparative analysis into a framework that can be applied more broadly to TD research on a range of sustainability issues in African cities.

\section{Findings and Discussion}

\section{Project 1: The State of Water and Energy Systems in Johannesburg and Kitwe}

The project in Diepsloot (Johannesburg) and Chambishi (Kitwe) explored the potential of decentralised renewable energy-powered water supply to mitigate the problems associated with inadequate access to affordable and clean water in growing township communities.

The study done in Diepsloot indicated that the majority of residents had some form of connection to a public decentralised source of water: $96 \%$ of survey respondents indicated that their source was municipal water provided through a tap within their yard or through a communal standpipe located within $500 \mathrm{~m}$ of their dwelling. Notwithstanding the widespread distribution, however, interruptions to the water supply were common, due in part to the inability of the municipality to keep up with the resource requirements of the growing population. The majority of respondents indicated that they experienced interruptions for up to five days a month. While the municipality often deploys water tankers as a stopgap measure during interruptions, only $14 \%$ of respondents indicated that the supply from the tankers reached them.

Public decentralised systems also played a significant role in sanitation: about $86 \%$ of respondents in the informal settlement used communal chemical toilets which were serviced weekly by the municipality (formal settlements are connected to the municipal sewerage network). The remainder relied on private decentralised systems, including pit latrines, buckets and/or open defecation for sanitation - alternatives that are not as safe as the service provided by the municipality but which users find accessible. Access to energy is more fraught: only 53\% of households in the settlement had access to public centralised electricity (i.e. electricity from the grid), while the remainder relied on private decentralised sources (paraffin, gas, solar and coal) for cooking, heating and lighting. Regardless of the energy source used, the majority of respondents reported not having an adequate supply 
to meet their daily requirements. Among those using public centralised electricity, power cuts were cited as the main reason for inadequacy.

In Chambishi, only a minority of residents had access to water from kiosks run by the Nkana Water and Sewerage Company, a public centralised utility. The water supplied through those kiosks was relatively high in quality but unreliable: during the researchers' visit to the study site, none of the ten water kiosks installed in the community was working due to damages to the pipes carrying water to the kiosks. Affordability was also an issue: even at the seemingly low cost of 0.125 cents per litre, many households in the settlement found it difficult to pay for a consistent supply from the kiosks. Given these gaps in the public supply, the majority of residents in the settlement (approximately 75\%) relied solely on private decentralised sources, chiefly poorly constructed water wells and bore holes, for their water.

Similarly, in the absence of a public centralised sewerage system, the majority of residents (approximately 98\%) used private decentralised options, mainly self-constructed pit latrines and open defecation, for their sanitation needs. The proximity and shoddy construction of the water wells and pit latrines have led to inadvertent contamination of the former by the latter. Gaps in reliability and affordability were also evident in energy access: the majority of residents in the community were not served by the Zambia Electricity Supply Corporation (ZESCO), the public centralised provider in the country. The fee of US\$ 161 charged by the utility to connect households to the grid is simply out of reach for many residents, leaving them reliant on low-quality, private decentralised energy sources such as firewood (62\%) and charcoal (36\%) for cooking and heating.

\section{Project 2: The Interconnections Between Food, Water and Energy Systems in Ouagadougou and Tamale}

The design of Project 2 in Ouagadougou and Tamale encouraged more reflexive engagement with local actors and systems than did that of Project 1. From the start, Project 2 aimed to gain a holistic understanding of the resource "value web' - the interconnections between actors at various levels of the life cycle of food and water wastes, from generation of the waste, through to its collection, and then its processing by collectors and urban farmers, and finally to its repurposing and use by urban horticulturists. The concept of a value web goes beyond that of the value chain to show how many chains are linked together and how they interact, branch out, intersect and affect each other (Suzanne et al., 2011). In the case of Project 2, the value web spans the food, water, energy and waste sectors, connecting various actors in a loose, organically developed network.

The value networks of food and water waste in the project cities are complex systems starting with the farmers and growers who generate the waste. Food and water waste streams take different paths from collection to disposal, or otherwise recycling and reuse. In both cities, three alternatives exist for recycling and reusing the respective waste streams: composting, wastewater treatment and biogas generation. Of the three, the composting alternative is the most developed locally, and it appears to have great potential for further development. 
About $80 \%$ of food growers surveyed in the project cities indicated that they would be willing to replace the chemical fertilisers they were using with compost if the latter were available. This would greatly improve soil fertility and constitute a big boon to the environment. From the perspective of local households, a similarly high proportion of those surveyed (nearly 90\%) reported that they would prefer to buy vegetables grown with compost if they were available on the market.

However, the other two repurposed resources are viewed less favourably by local actors. Treated water is only used in small quantities by urban farmers because they do not trust its source. In Ouagadougou, $90 \%$ of the urban farmers surveyed had reservations about the quality of treated water supplied by the National Office for Water and Sanitation (ONEA), the public centralised water authority. Many of those farmers have resorted to working during the rainy season (which lasts about half the year) so that they can mix water from the public source with water from makeshift decentralised ponds filled by the rains. Some farmers produce biogas from manure and septic sludge for household consumption as well as community use, constituting examples of both public and private decentralised systems. Larger-scale, albeit still decentralised biogas applications also exist, with private companies such as FasoBiogaz in Ouagadougou and Biogas Technologies Africa Limited in Tamale using the gas produced for electricity generation. However, with only about 22,000 households in Burkina Faso currently served by biogas according to expert interviews, the contribution of this resource to national energy mixes is negligible.

Two common threads run through the projects described above. The first is that private decentralised systems continue to play an important role for the urban poor regardless of the degree of coverage attained by other systems. The second is that, notwithstanding the continued relevance of private decentralised systems to the functioning of the project cities, there has been little systematic engagement between them and public systems, leaving poor residents to struggle with limited access to food, water and energy services. The paper goes on to detail how researchers on both projects attempted to mediate these critical but missing system interactions in their respective contexts, the outcomes of those processes and aspects of the transdisciplinary approach that contributed to the relative success of Project 2 in this regard.

\section{The Value of Transdisciplinary Research for Facilitating Knowledge Co-Production and Inclusive Service Delivery}

Project 1 illustrates the potential for integrating systems to enable better access to water and energy services by the poor, as well as the problems raised by the prospect. We see how, even though Diepsloot and Chambishi have similar socioeconomic profiles, city and municipal authorities are much more invested in the provision of those services in the former than in the latter. Indeed, the situation regarding service provision in Diepsloot is somewhat opposite to that in Chambishi: the prevalence of public systems in the former stands in stark contrast to the widespread 
Public systems

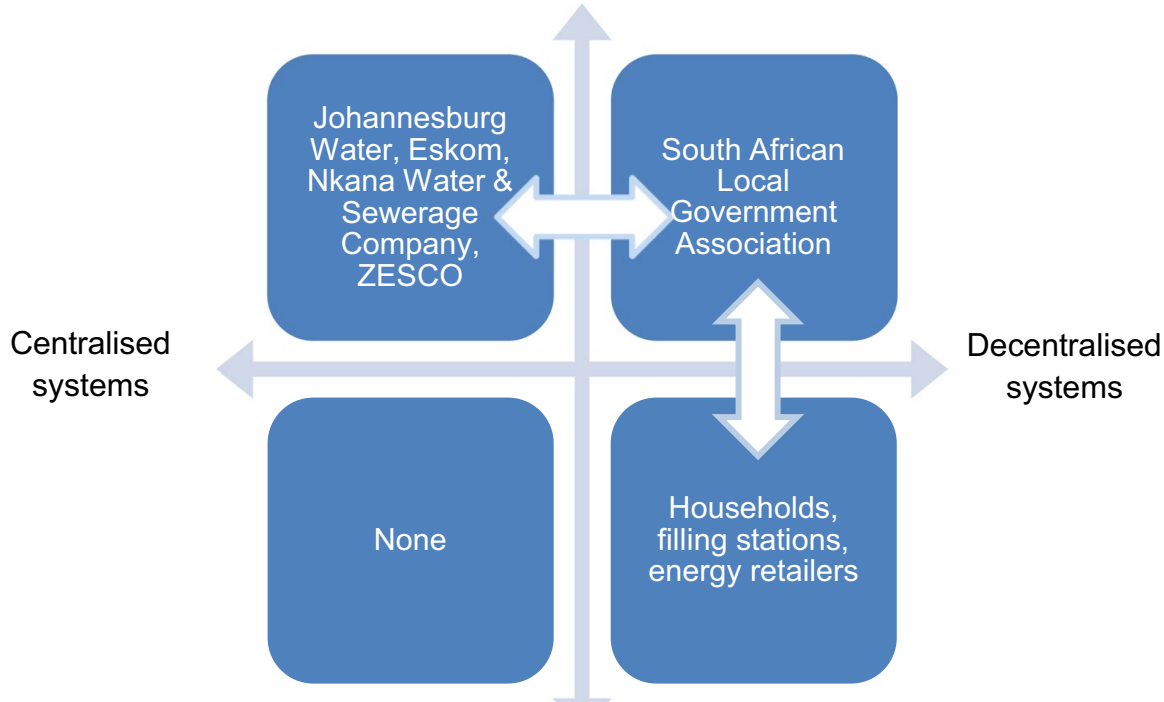

Private systems

Fig. 5 The actor and system interactions enabled by the transdisciplinary approach employed on Project 1

reliance on private decentralised systems in the latter. However, even in Diepsloot, gaps exist in the capacity of the public infrastructure to reach residents, indicating that there is a continuing role in the context for decentralised systems, both public and private. Project 1 highlighted this and identified suitable decentralised options for water treatment and energy generation based on the resource assessments and community engagements that were undertaken as part of the project. However, subsequent engagement with municipality authorities revealed that they were more inclined to extend existing public services — the associated challenges (most notably, a lack of funding) notwithstanding - than they were to explore the potential of the novel decentralised systems (namely, biogas-powered water treatment plants) shown by the project to be feasible.

Figure 5 shows the actor configuration within the different systems involved in Project 1. As the two-way arrows signify, the transdisciplinary approach used on the project enabled collaborative modes of working among actors at different levels; however, the approach was ultimately limited in the sense that it left the outlook for more substantive interactions between each of those self-contained systems largely unchanged. This case appears to reinforce the notion, described above, that decision makers in African cities retain a normative preference for formal systems; however, as Project 2 illustrates, co-production processes can result in actors across different systems and scales forging alliances and emerging with solutions that are both inclusive and innovative. 


\section{Public systems}

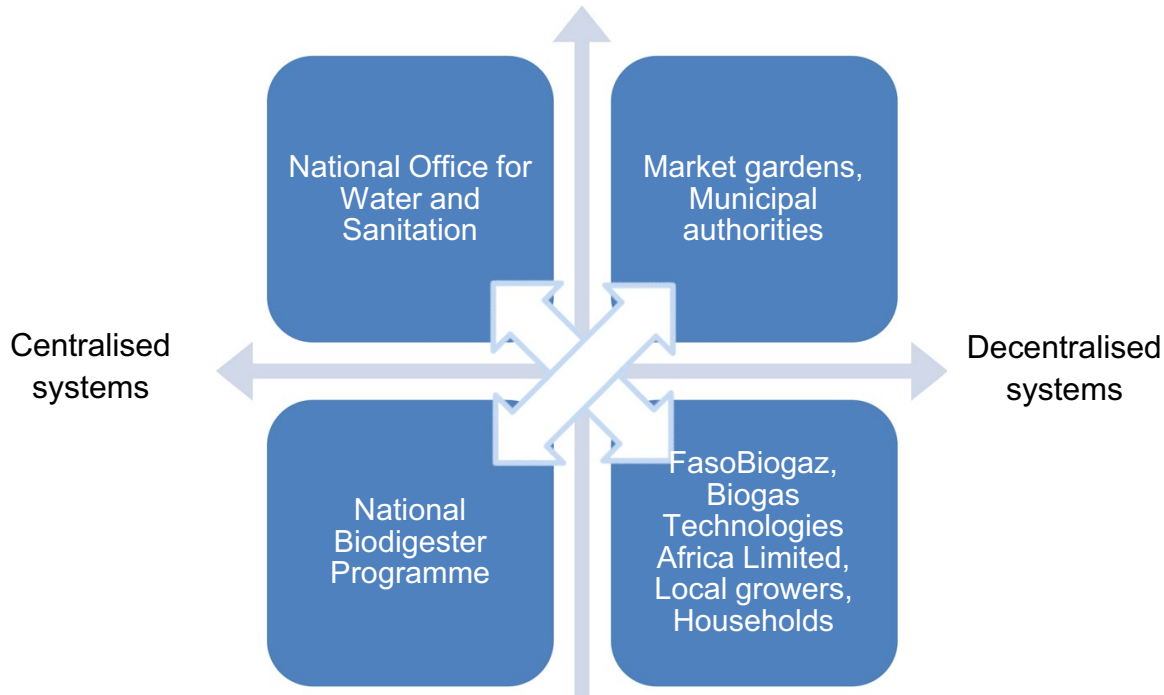

Private systems

Fig. 6 The actor and system interactions enabled by the transdisciplinary approach employed on Project 2

As earlier indicated, the stakeholder workshops convened by the researchers on Project 2 were designed to facilitate mutual understanding of the value-adding components of the food-water-energy 'web' among actors and the interactions that enable their optimisation. Waste serves as an important 'boundary object' (Harrison et al., 2018) for actors across these three systems, as the resource is generated during the production and consumption of food and water and is, in turn, used in the production of energy (i.e. biogas). Boundary objects like this are important for their ability to stimulate engagement and establish common ground for action among actors whose interests might otherwise be perceived as disparate or even conflicting (ibid.; Fox, 2011; Turnhout, 2009).

In the case of Project 2, the boundary object — waste - facilitated the identification of obstacles to the optimal application and management of the resource by actors across the spectrum. Those obstacles included: a dearth of measures to curb the indiscriminate dumping of waste; inadequate maintenance of waste collection equipment and an overall lack of sophistication evident in the rudimentary approaches to handling waste at different stages; and the de facto status of informality among waste collectors and processors occasioned by the failure of municipalities to sign formal contracts with them.

Importantly, the engagements showed that intangible variables flow through the value web - notably, knowledge and power, both of which are interdependent. The most powerful actors in the respective value webs of the project cities 
are government agencies, given that they control access to the resources (land and water) upon which private actors depend. At the stakeholder workshops, some private actors reported being fearful that resources could be taken away from them if they were perceived as being hostile towards, or critical of, public agencies and administrators. This has resulted in a culture of silence on one extreme and outward aggression on the other, rendering productive dialogue between public and private actors very difficult.

Through the processes of knowledge co-production and exchange facilitated by the project, some of the longstanding barriers to the integration of public and private systems in the study areas were lowered. Some gains became immediately apparent, including the establishment of channels of communication between national-level agencies and urban farmers in Ouagadougou regarding the quality of treated water used in market gardens, and the issuing of a moratorium on plans by city authorities to evict plant nursery owners from the spaces they occupy in the city. This is significant progress in a context where, as was highlighted earlier, actors in such private decentralised systems often operate on the margins and outside of the purview of formal structures. Figure 6 depicts how the transdisciplinary approach used on Project 2 transformed actor/system relations to a higher degree than it did on Project 1.

\section{Contributions to the Theory and Practice of Transdisciplinary Research in Africa}

As several studies have pointed out, TD research projects typically lend themselves to case study design on account of their focus on the dynamics of specific local contexts (see, for example, Brandt et al., 2013; Kirby, 2019). We have adopted this design in our study, focusing as we have done on the enablers of micro-level interactions between actors and systems in selected African cities. This approach might, at first glance, appear to limit the relevance of transdisciplinary projects, especially in terms of their potential to contribute to the body of ' $\mathrm{T} 1$ ' research that Sakao and Brambila-Macias (2018) have identified as being critical for advancing the frontiers of sustainability science.

A few studies (for example, Ambole et al., 2019; Lang et al., 2012), however, demonstrate the possibility, and even desirability, of synthesising the findings from TD research conducted in different local contexts into overarching principles that can be more widely applied and re-interpreted within the framework of other contexts. We follow this example here in explicating the processes and outcomes from two different localised projects and then contrasting them to draw out a broad set of learnings that can contribute to improved TD practice for inclusive service delivery in other African contexts. In particular, we interrogate aspects of the co-production approach employed on Project 2 that enabled the relatively high levels of integration and inclusiveness realised and codify them into a sequential, albeit non-linear, framework for implementing similar projects in different settings. This framework, outlined in Table 2, is intended to serve as a guide to local researchers seeking to engage system and institutional actors in knowledge co-production processes relating to the discourse and practice of sustainability in African cities. 


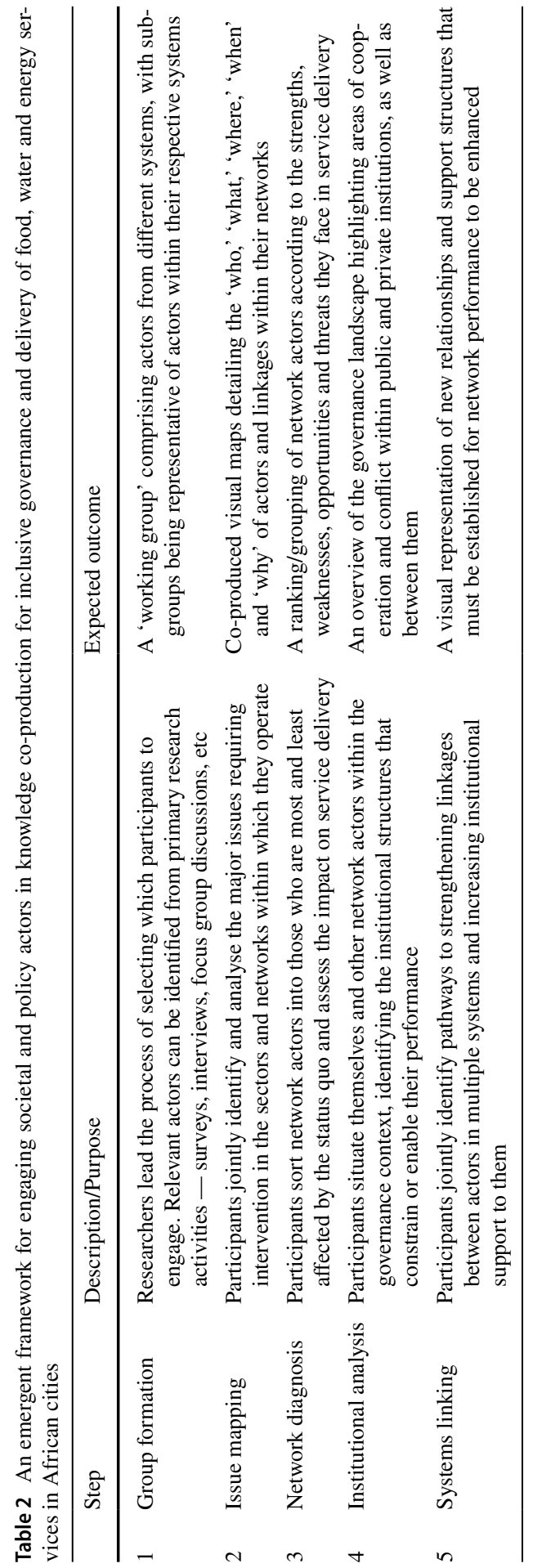


Beyond the methodical application of the steps outlined in this framework, the researchers on Project 2 paid attention to some of the more subtle dynamics that influence outcomes in co-production settings. Crucially, by engaging all actors on an equitable basis from the beginning of the project (Steynor et al., 2016), the researchers succeeded in facilitating a high degree of 'reflexive learning' (Hirsch Hadorn et al., 2006, p.122) and consequent reorientation among those actors. Some of the steps outlined in the framework have been identified in earlier studies, articulated in such concepts as 'joint fact finding' (Steynor et al., 2016, p.96) and 'issue framing' (Brennan \& Rondón-Sulbarán, 2019; Roux et al., 2010). However, those concepts are typically put forward as normative principles which are then applied in carrying out specific TD research projects. Our framework instead takes empirical findings from specific projects and condenses them into principles, recursively reinforcing key concepts represented in the literature and closing the feedback loop between theory and practice.

\section{Conclusion}

This paper has analysed how stakeholder engagement and co-production processes contributed to the shaping of knowledge and practices among multiple actors in food, water and energy systems in four African cities (Johannesburg, Kitwe, Ouagadougou and Tamale). Our analysis demonstrates the value of using a transdisciplinary approach to facilitate interactions between actors and systems for more inclusive outcomes in contexts with high poverty and inequality where, as Soma et al. (2018) note, such analyses are as rare as they are needed.

Our study provides evidence for the utility of nurturing hybrid models of governance and service delivery that emphasise interaction among all actors along the public-private, centralised-decentralised axes identified in our conceptual framework. The rationale here is that each of those actor/system categories embodies strengths and weaknesses that are unique to them and, given the need for adaptability and flexibility in the rapidly growing contexts under consideration, a composite of these characteristics is required. For example, while private decentralised services are often (though not always) accessible and affordable for the urban poor, low levels of capitalisation and productivity often constrain the ability of the actors involved to operate in ways that are economically and environmentally sustainable. Centralised systems, on the other hand, are generally better-resourced than their decentralised counterparts, but they often lack the flexibility to respond to the real-time changes in urban residents' demand for crucial services. Municipal and city-wide governance models that recognise and harness the complementarities between these systems while building their respective capacities would enable more equitable and efficient distribution of food, water and energy services in the complex contexts exemplified by Projects 1 and 2 .

The differential outcomes of both projects with respect to facilitating inclusive systems indicate that it is not sufficient for researchers to aim to do 'good science' (Rosser, 1988, p.13); rather, scientific results need to be translated into realworld contexts, and researchers have a role to play in mediating this process. Our 
experience portrays TD research as a two-layered, iterative process, where the first layer sees academics involving societal and policy actors in their conduct of scientific research, and the second focuses on engaging those actors in interpreting research findings in ways that are feasible for them to implement locally. This latter aspect of engagement is particularly challenging for many researchers, as success depends on developing a good understanding of relevant contextual factors as well as the ability to negotiate them.

As seen from Project 2, the engagement process, if conducted with sensitivity to the context, can boost the agency of less powerful actors like the private decentralised service providers who are particularly disadvantaged in the power and governance structures of African cities. Further, both projects illustrate the central role of municipal and/or city governments in providing support to system actors, and how this support can be constrained or enabled depending on the policy and institutional stance of the former towards the latter. The outcomes of Project 2 indicate that TD research can help bring city authorities closer to the realities of system actors and inform more responsive policies and practices.

Lastly, the paper presented an empirically generated framework for facilitating mutually reinforcing interactions among actors within city ecosystems. We have shown how the framework originated in the context of food, water and energy system interactions; further research testing its applicability to a wider range of urban sustainability issues would be instructive. In administering this framework, the primary role of researchers should be to broker knowledge rather than be the sole generators of it, giving due consideration to the inputs of different actors in the process (Cairney \& Oliver, 2018). As Boswell and Smith (2017) and Wowk et al. (2017) point out, doing so would entail a shift by individual researchers and academic institutions away from traditional understandings of what constitutes excellent research and seeing societal and policy impact as an integral component of this measure.

Author Contribution All the authors contributed to the study conception and design. Data collection, analysis and stakeholder engagement were performed by Safietou Sanfo and Keneiloe Sikhwivhilu. The literature review was conducted by Francis Dakyaga and Dzidzo Yirenya-Tawiah. The conceptual framework was developed by Temilade Sesan. The methods used were compiled by Fati Aziz, Mercy Badu, Safietou Sanfo and Keneiloe Sikhwivhilu. Material for the introduction and conclusion sections was provided by Emmanuel Derbile, Mercy Ojoyi, Boubacar Ibrahim and Rabani Adamou. Author contributions were synthesised into a complete draft by Temilade Sesan. All authors read and approved the final manuscript.

Funding This work was funded by a collaborative writing grant from the International Science Council (grant number LIRA2030-GR08/20), under its Leading Integrated Research for Agenda 2030 in Africa ('LIRA 2030') programme. The original case study projects were funded through separate LIRA 2030 grants, with grant numbers LIRA2030-GR06/17 (Project 1) and LIRA2030-GR09/18 (Project 2) respectively.

Data Availability The datasets generated and analysed during the current study are not publicly available due to the sensitivity of the policy context in the project cities, but they are available from the corresponding author on reasonable request. 


\section{Declarations}

Competing Interests The authors declare no competing interests.

Open Access This article is licensed under a Creative Commons Attribution 4.0 International License, which permits use, sharing, adaptation, distribution and reproduction in any medium or format, as long as you give appropriate credit to the original author(s) and the source, provide a link to the Creative Commons licence, and indicate if changes were made. The images or other third party material in this article are included in the article's Creative Commons licence, unless indicated otherwise in a credit line to the material. If material is not included in the article's Creative Commons licence and your intended use is not permitted by statutory regulation or exceeds the permitted use, you will need to obtain permission directly from the copyright holder. To view a copy of this licence, visit http://creativecommons.org/licen ses/by/4.0/.

\section{References}

Abubakar, I. R. (2016). Quality dimensions of public water services in Abuja, Nigeria. Utilities Policy, $38,43-51$.

Adams, E. A., \& Zulu, L. C. (2015). Participants or customers in water governance? Community-Public Partnerships for Peri-Urban Water Supply, Geoforum, 65, 112-124.

Adebiyi, J. A., Olabisi, L. S., Liu, L., \& Jordan, D. (2021). Water-food-energy-climate nexus and technology productivity: A Nigerian case study of organic leafy vegetable production. Environment, Development and Sustainability, 23(4), 6128-6147.

Aguiar, A. P. D., Collste, D., Harmáčková, Z. V., Pereira, L., Odirilwe, S., Galafassi, D., Van Vuuren, D., \& Van Der Leeuwi, S. (2020). Co-designing global target-seeking scenarios: A cross-scale participatory process for capturing multiple perspectives on pathways to sustainability. Global Environmental Change, 65, 102198. https://doi.org/10.1016/j.gloenvcha.2020.102198

Ambole, A., Musango, J. K., Buyana, K., Ogot, M., Anditi, C., Mwau, B., Kovacic, Z., Smit, S., Lwasa, S., Nsangi, G., Sseviiri, H., \& Brent, A. C. (2019). Mediating household energy transitions through co-design in urban Kenya, Uganda and South Africa. Energy Research \& Social Science, 55, 208217. https://doi.org/10.1016/j.erss.2019.05.009

Aparcana, S. (2017). Approaches to formalization of the informal waste sector into municipal solid waste management systems in low- and middle-income countries: Review of barriers and success factors. Waste Management, 61, 593-607.

Araral, E. (2009). The failure of water utilities privatization: Synthesis of evidence, analysis and implications. Policy and Society, 27(3), 221-228.

Batinge, B., Musango, J. K., \& Brent, A. C. (2017). Leapfrogging to renewable energy: The opportunity for unmet electricity markets. The South African Journal of Industrial Engineering, 28(4), 32-49. https://doi.org/10.7166/28-4-1702

Battersby, J. (2013). Hungry cities: A critical review of urban food security research in sub-Saharan African cities. Geography Compass, 7(7), 452-463. https://doi.org/10.1111/gec3.12053

Bel, G., \& Warner, M. (2008). Does privatization of solid waste and water services reduce costs? A review of empirical studies. Resources, Conservation and Recycling, 52(12), 1337-1348.

Boswell, C. \& Smith, K. (2017). Rethinking policy 'impact': Four models of research-policy relations. Palgrave Communications 3 (44). https://doi.org/10.1057/s41599-017-0042-Z

Brandt, P., Ernst, A., Gralla, F., Luederitz, C., Lang, D. J., Newig, J., Reinert, F., Abson, D. J., \& Von Wehrden, H. (2013). A review of transdisciplinary research in sustainability science. Ecological Economics, 92, 1-15.

Brennan, M., \& Rondón-Sulbarán, J. (2019). Transdisciplinary research: Exploring impact, knowledge and quality in the early stages of a sustainable development project. World Development, 122, 481491. https://doi.org/10.1016/j.worlddev.2019.06.001 
Brister, E. (2016). Disciplinary capture and epistemological obstacles to interdisciplinary research: Lessons from central African conservation disputes. Studies in History and Philosophy of Science Part C, 56, 82-91. https://doi.org/10.1016/j.shpsc.2015.11.001

Cairney, P. \& Oliver, K. (2018). How should academics engage in policymaking to achieve impact? Political Studies Review 1-17.https://doi.org/10.1177/1478929918807714

Castro, J. E. (2007). Poverty and citizenship: Sociological perspectives on water services and public-private participation. Geoforum, 38(5), 756-771.

Cheng, C., \& Urpelainen, J. (2015). Who should take the garbage out? Public opinion on waste management in Dar es Salaam, Tanzania. Habitat International, 46, 111-118.

Cobbinah, P. B., Addaney, M., \& Agyeman, K. O. (2017). Locating the role of urbanites in solid waste management in Ghana. Environmental Development, 24, 9-21.

Dakyaga, F., Ahmed, A., \& Sillim, M. L. (2020). Governing ourselves for sustainability: Everyday ingenuities in the governance of water infrastructure in the informal settlements of Dar es Salaam. Urban Forum, 32(1), 111-129. https://doi.org/10.1007/s12132-020-09412-6

Dellas, E. (2011). CSD water partnerships: Privatization, participation and legitimacy. Ecological Economics, 70(11), 1916-1923.

Devkar, G. A., Mahalingam, A., Deep, A., \& Thillairajan, A. (2013). Impact of private sector participation on access and quality in provision of electricity, telecom and water services in developing countries: A systematic review. Utilities Policy, 27, 65-81.

Dos Santos, S., Adams, E. A., Neville, G., Wada, Y., de Sherbinin, A., Bernhardt, E. M., \& Adamo, S. B. (2017). Urban growth and water access in sub-Saharan Africa: Progress, challenges, and emerging research directions. Science of the Total Environment, 607-608, 497-508.

Dungumaro, E. W., \& Madulu, N. F. (2003). Public participation in integrated water resources management: The case of Tanzania. Physics and Chemistry of the Earth, Parts a/b/c, 28(20-27), 1009-1014.

Esler, K. J., Downsborough, L., Roux, D. J., Blignaut, J., Milton, S., le Maitre, D., \& de Wit, M. P. (2016). Interdisciplinary and multi-institutional higher learning: Reflecting on a South African case study investigating complex and dynamic environmental challenges. Current Opinion in Environmental Sustainability, 19, 76-86. https://doi.org/10.1016/j.cosust.2015.12.002

Filho, W. L., Azeiteiro, U., Alves, F., Pace, P., Mifsud, M., Brandli, L., Caeiro, S. S., \& Disterheft, A. (2018). Reinvigorating the sustainable development research agenda: The role of the sustainable development goals (SDG). International Journal of Sustainable Development \& World Ecology, 25(2), 131-142. https://doi.org/10.1080/13504509.2017.1342103

Fischer, J., Gardner, T. A., Bennett, E. M., Balvanera, P., Biggs, R., Carpenter, S., Daw, T., Folke, C., Hill, R., Hughes, T. P., Luthe, T., Maass, M., Meacham, M., Norström, A. V., Peterson, G., Queiroz, C., Seppelt, R., Spierenburg, M., \& Tenhunen, J. (2015). Advancing sustainability through mainstreaming a social-ecological systems perspective. Current Opinion in Environmental Sustainability, 14, 144-149. https://doi.org/10.1016/j.cosust.2015.06.002

Fox, N. J. (2011). Boundary objects, social meanings and the success of new technologies. Sociology, 45(1), 70-85. https://doi.org/10.1177/0038038510387196

Frayne, B., \& McCordic, C. (2015). Planning for food secure cities: Measuring the influence of infrastructure and income on household food security in Southern African cities. Geoforum, 65, 1-11. https://doi.org/10.1016/j.geoforum.2015.06.025

GSS and MoH (2008). Ghana - Demographic and Health Survey 2008. Accra: Ghana Statistical Service and Ministry of Health.

Güneralp, B., Lwasa, S., Masundire, H., Parnell, S. \& Seto, K. (2017). Urbanization in Africa: Challenges and opportunities for conservation. Environmental Research Letters 13.https://doi.org/10. 1088/1748-9326/aa94fe

Hadorn, G. H., Hoffmann-Riem, H., Biber-Klemm, S., Grossenbacher-Mansuy, W., Joye, D., Pohl, C., Wiesmann, U., \& Zemp, E. (Eds.). (2008). Handbook of transdisciplinary research. Springer Netherlands. https://doi.org/10.1007/978-1-4020-6699-3

Harrison, D., Hoholm, T., Prenkert, F., \& Olsen, P. I. (2018). Boundary objects in network interactions. Industrial Marketing Management, 74, 187-194. https://doi.org/10.1016/j.indmarman.2018.04.006

Herslund, L. \& Mguni, P. (2019). Examining urban water management practices - Challenges and possibilities for transitions to sustainable urban water management in Sub-Saharan cities. Sustainable Cities and Society 48, 101573. 
Hirsch Hadorn, G., Bradley, D., Pohl, C., Rist, S., \& Wiesmann, U. (2006). Implications of transdisciplinarity for sustainability research. Ecological Economics, 60(1), 119-128. https://doi.org/10.1016/j. ecolecon.2005.12.002

Hottle, R. \& Damassa, T. (2018). Mitigating poverty and climate change: How reducing short-lived climate pollutants can support pro-poor, sustainable development. Oxfam Research Backgrounder series: https://www.oxfamamerica.org/explore/research-publications/mitigating-povertyand-clima te-change/. Accessed 26 Aug 2021

Hubbard, M., \& Onumah, G. (2001). Improving urban food supply and distribution in developing countries: The role of city authorities. Habitat International, 25(3), 431-446.

INSD (2017). Annuaire Statistique 2016. Ouagadougou: Insitut national de la statistique et de la démographie.

International Science Council (ISC). (2020). Advancing the 2030 Agenda in African cities through knowledge co-production: Urban experiments led by early-career African scientists. International Science Council.

Jahn, T., Bergmann, M., \& Keil, F. (2012). Transdisciplinarity: Between mainstreaming and marginalization. Ecological Economics, 79, 1-10. https://doi.org/10.1016/j.ecolecon.2012.04.017

Jimu, I. M. (2008). The role of stakeholders in the provision and management of water kiosks in Nkolokoti, Blantyre (Malawi). Physics and Chemistry of the Earth, Parts a/b/c, 33(8-13), 833-840.

Jones, S. (1995). Food market reform: The changing role of the state. Food Policy, 20(6), 551-560.

Kaviti Musango, J., Currie, P., Smit, S., \& Kovacic, Z. (2020). Urban metabolism of the informal city: Probing and measuring the 'unmeasurable' to monitor Sustainable Development Goal 11 indicators. Ecological Indicators, 119, 106746. https://doi.org/10.1016/j.ecolind.2020.106746

Kirby, A. (2019). Transdisciplinarity and sustainability science: A response to Sakao and BrambilaMacias in the context of sustainable cities research. Journal of Cleaner Production, 210, 238-245. https://doi.org/10.1016/j.jclepro.2018.11.003

Lang, D. J., Wiek, A., Bergmann, M., Stauffacher, M., Martens, P., Moll, P., Swilling, M., \& Thomas, C. J. (2012). Transdisciplinary research in sustainability science: Practice, principles, and challenges. Sustainability Science, 7(S1), 25-43. https://doi.org/10.1007/s11625-011-0149-X

Leck, H., Pelling, M., Adelekan, I., Dodman, D., Issaka, H., Johnson, C., Manda, M., Mberu, B., Nwokocha, E., Osuteye, E., \& Boubacar, S. (2018). Towards risk-sensitive and transformative urban development in Sub Saharan Africa. Sustainability, 10(8), 2645. https://doi.org/10.3390/su10082645

Lefore, N., Closas, A., \& Schmitter, P. (2021). Solar for all: A framework to deliver inclusive and environmentally sustainable solar irrigation for smallholder agriculture. Energy Policy, 154, 112313.

Lourenco-Lindell, I. (1995). The informal food economy in a peripheral urban district: The case of Bandim district. Bissau. Habitat International, 19(2), 195-208.

Lucas, P. L., Hilderink, H. B., Janssen, P. H., Samir, K. C., van Vuuren, D. P., \& Niessen, L. (2019). Future impacts of environmental factors on achieving the SDG target on child mortality-A synergistic assessment. Global Environmental Change, 57, 101925.

Matsinhe, N. P., Juízo, D., Macheve, B., \& dos Santos, C. (2008). Regulation of formal and informal water service providers in peri-urban areas of Maputo, Mozambique. Physics and Chemistry of the Earth, Parts a/b/c, 33(8-13), 841-849.

Max-Neef, M. A. (2005). Foundations of transdisciplinarity. Ecological Economics, 53(1), 5-16. https:// doi.org/10.1016/j.ecolecon.2005.01.014

Mbuvi, D., De Witte, K., \& Perelman, S. (2012). Urban water sector performance in Africa: A step-wise bias corrected efficiency and effectiveness analysis. Utilities Policy, 22, 31-40.

Mguni, P., van Vliet, B., Spaargaren, G., Nakirya, D., Osuret, J., Isunju, J. B., Ssekamatte, T. \& Mugambe, R. (2020). What could go wrong with cooking? Exploring vulnerability at the water, energy and food Nexus in Kampala through a social practices lens. Global Environmental Change, 63, 102086.

Mugabi, J., Kayaga, S., \& Njiru, C. (2007). Strategic planning for water utilities in developing countries. Utilities Policy, 15(1), 1-8.

Niessen, L. W., Mohan, D., Akuoku, J. K., Mirelman, A. J., Ahmed, S., Koehlmoos, T. P., Trujillo, A., Khan, J., \& Peters, D. H. (2018). Tackling socioeconomic inequalities and non-communicable diseases in low-income and middle-income countries under the Sustainable Development agenda. Lancet (london, England), 391(10134), 2036-2046. https://doi.org/10.1016/S0140-6736(18)30482-3

Nyiwul, L. (2021). Climate change adaptation and inequality in Africa: Case of water, energy and food insecurity. Journal of Cleaner Production, 278, 123393. 
Peyton, S., Moseley, W., \& Battersby, J. (2015). Implications of supermarket expansion on urban food security in Cape Town. South Africa. African Geographical Review, 34(1), 36-54. https://doi.org/ $10.1080 / 19376812.2014 .1003307$

Pohl, C. (2011). What is progress in transdisciplinary research? Futures, 43(6), 618-626. https://doi.org/ 10.1016/j.futures.2011.03.001

Pohl, C., Truffer, B. \& Hirsch Hadorn, G. (2017). Addressing wicked problems through transdisciplinary research. In R. Frodeman, J. Thompson Klein, \& R. C. S. Pacheco (Eds.), The Oxford Handbook of Interdisciplinarity, pp. 319-331.

Poulsen, M. N., McNab, P. R., Clayton, M. L., \& Neff, R. A. (2015). A systematic review of urban agriculture and food security impacts in low-income countries. Food Policy, 55, 131-146.

Rabaey, K., Vandekerckhove, T., Van de Walle, A. \& Sedlak, D. L. (2020). The third route: Using extreme decentralization to create resilient urban water systems. Water Research 185, 116276.

Rist, S., Zimmermann, A. \& Wiesmann, U. (2004). From epistemic monoculture to cooperation between epistemic communities - Lessons learnt from development research. Paper presented at the International Conference "Bridging Epistemologies". Millennium Assessment. March 17-20, Alexandria, Egypt.

Robin, E., Steenmans, K., \& Acuto, M. (2019). Harnessing inclusive urban knowledge for the implementation of the New Urban Agenda. Urban Research \& Practice, 12(2), 137-155. https://doi. org/10.1080/17535069.2017.1414870

Rosser, S. V. (1988). Good science: Can it ever be gender free? Women's Studies International Forum, 11(1), 13-19.

Roux, D. J., Stirzaker, R. J., Breen, C. M., Lefroy, E. C., \& Cresswell, H. P. (2010). Framework for participative reflection on the accomplishment of transdisciplinary research programs. Environmental Science \& Policy, 13(8), 733-741. https://doi.org/10.1016/j.envsci.2010.08.002

Runsten, S., Nerini, F. F., \& Tait, L. (2018). Energy provision in South African informal urban settlements - A multi-criteria sustainability analysis. Energy Strategy Reviews, 19, 76-84.

Sakao, T., \& Brambila-Macias, S. A. (2018). Do we share an understanding of transdisciplinarity in environmental sustainability research? Journal of Cleaner Production, 170, 1399-1403. https:// doi.org/10.1016/j.jclepro.2017.09.226

Saltelli, A., \& Funtowicz, S. (2017). What is science's crisis really about? Futures, 91, 5-11. https:// doi.org/10.1016/j.futures.2017.05.010

Sarewitz, D. (2016). Saving science. The. New Atlantis, 49(1), 4-40.

Schafer, M., Ohlhorst, D., Schon, S., \& Kruse, S. (2010). Science for the future: Challenges and methods for transdisciplinary sustainability research. African Journal of Science, Technology, Innovation and Development, 2 (1), 114-137. https://doi.org/10.10520/EJC10527

Schneider, F., Giger, M., Harari, N., Moser, S., Oberlack, C., Providoli, I., et al. (2019). Transdisciplinary co-production of knowledge and sustainability transformations: Three generic mechanisms of impact generation. Environmental Science \& Policy, 102, 26-35.

Schreiner, B., \& Baleta, H. (2015). Broadening the lens: A regional perspective on water, food and energy Integration in SADC. Acquatic Procedia, 5, 90-103. https://doi.org/10.1016/j.aqpro. 2015.10.011

Schwartz, K., Gupta, J., \& Tutusaus, M. (2018). Editorial - Inclusive development and urban water services. Habitat International, 73, 96-100.

Sesan, T., \& Siyanbola, W. (2021). "These are the realities": Insights from facilitating researcherpolicymaker engagement in Nigeria's household energy sector. Humanities and Social Sciences Communications, 8(1), 73. https://doi.org/10.1057/s41599-021-00754-5

Sichilima, S., Siame, J., Sikhwivhilu, K., Mutanga, S.S., Mwandila, G., Maseka, K.K., Mukosha, L., Makhafola, M and Simposya, A. (2017). Energy-water nexus in sub-Saharan Africa - Biogassupported decentralised water treatment for urban communities: A case of Chambishi (Zambia) and Diepsloot (South Africa). Conference paper. International Conference on Energy, Environment and Climate - ICEECC 2017.

Sima, L. C., Kelner-Levine, E., Eckelman, M. J., McCarty, K. M., \& Elimelech, M. (2013). Water flows, energy demand, and market analysis of the informal water sector in Kisumu, Kenya. Ecological Economics, 87, 137-144.

Simatele, D., \& Etambakonga, C. L. (2015). Scavenging for solid waste in Kinshasa: A livelihood strategy for the urban poor in the Democratic Republic of Congo. Habitat International, 49, 266-274. 
Smith, H., \& Jenkins, P. (2015). Trans-disciplinary research and strategic urban expansion planning in a context of weak institutional capacity: Case study of Huambo, Angola. Habitat International, $46,244-251$.

Smith, A., Fressoli, M., Abrol, D., Arond, E., \& Ely, A. (2017). Grassroots Innovation Movements. Routledge.

Soma, K., Dijkshoorn-Dekker, M. W. C., \& Polman, N. B. P. (2018). Stakeholder contributions through transitions towards urban sustainability. Sustainable Cities and Society, 37, 438-450. https://doi.org/ 10.1016/j.scs.2017.10.003

Sood, A., Nicol, A., \& Arulingam, I. (2019). Unpacking the water-energy-environment-food nexus: Working across systems. Colombo, Sri Lanka: International Water Management Institute (IWMI). IWMI Working Paper 186. https://doi.org/10.5337/2019.210

Steynor, A., Padgham, J., Jack, C., Hewitson, B., \& Lennard, C. (2016). Co-exploratory climate risk workshops: Experiences from urban Africa. Climate Risk Management, 13, 95-102. https://doi.org/ 10.1016/j.crm.2016.03.001

Sukholthaman, P., Shirahada, K., \& Sharp, A. (2017). Toward effective multi-sector partnership: A case of municipal solid waste management service provision in Bangkok. Thailand. Kasetsart Journal of Social Sciences, 38(3), 324-330.

Suzanne, N., Wongtschowski, M., \& van der Lee, F. (2011). Putting heads together: Agricultural innovation platforms in practice. Bulletin 396, KIT Publishers. Bulletin 396, January 2011, 192.

Tan, J. (2012). The pitfalls of water privatization: Failure and reform in Malaysia. World Development, 40(12), 2552-2563.

Terrapon-Pfaff, J., Ortiz, W., Dienst, C., \& Gröne, M. C. (2018). Energising the WEF nexus to enhance sustainable development at local level. Journal of Environmental Management, 223, 409-416. https://doi.org/10.1016/j.jenvman.2018.06.037

Turnhout, E. (2009). The effectiveness of boundary objects: The case of ecological indicators. Science and Public Policy 36 (2009) 5, 36. https://doi.org/10.3152/030234209X442007

UNDESA. (2018). The sustainable development goals report. United Nations Department of Economic and Social Affairs.

UNDESA (undated). The World's Cities in 2016. Available at: https://www.un.org/en/development/desa/ population/publications/pdf/urbanisation/the_worlds_cities_in_2016_data_booklet.pdf. Accessed 19 February 2021.

UN-Habitat (2003). The challenge of slums: Global report on human settlements. London and Sterling, VA: Earthscan.

Visagie, E. (2008). The supply of clean energy services to the urban and peri-urban poor in South Africa. Energy for Sustainable Development, 12(4), 14-21.

Wahl, D. C., \& Baxter, S. (2008). The designer's role in facilitating sustainable solutions. Design Issues, 24(2), 72-83. https://doi.org/10.1162/desi.2008.24.2.72

Wowk, K., McKinney, L., Muller-Karger, F., Moll, R., Avery, S., Escobar-Briones, E., Yoskowitz, D. \& McLaughlin, R. (2017). Evolving academic culture to meet societal needs. Palgrave Communications 3(35).

WWAP (United Nations World Water Assessment Programme). (2014). The United Nations World Water Development Report 2014: Water and Energy. UNESCO.

Publisher's Note Springer Nature remains neutral with regard to jurisdictional claims in published maps and institutional affiliations. 


\section{Authors and Affiliations}

Temilade Sesan ${ }^{1}$ (1) Safietou Sanfo ${ }^{2} \cdot$ Keneiloe Sikhwivhilu $^{3} \cdot$ Francis Dakyaga $^{4}$. Fati Aziz ${ }^{5}$. Dzidzo Yirenya-Tawiah ${ }^{6} \cdot$ Mercy Badu $^{7}$. Emmanuel Derbile ${ }^{4}$. Mercy Ojoyi ${ }^{8} \cdot$ Boubacar Ibrahim $^{9} \cdot$ Rabani Adamou $^{9}$

1 Centre for Petroleum, Energy Economics and Law, University of Ibadan, Ibadan, Nigeria

2 West African Science Service Centre On Climate Change and Adapted Land Use, Ouagadougou, Burkina Faso

3 DSI/Mintek Nanotechnology Innovation Centre, Mintek, Randburg, South Africa

4 SD Dombo University of Business and Integrated Development Studies, Wa, Ghana

5 Department of Ecology and Conservation Biology, Texas A\&M University, College Station, TX 77843, USA

6 Institute for Environment and Sanitation Studies, University of Ghana, Accra, Ghana

7 Kwame Nkrumah University of Science and Technology, Kumasi, Ghana

8 University of Pretoria, Pretoria, South Africa

9 Université Abdou Moumouni, Niamey, Niger 